\title{
The coal lumpers of Sydney
}

\section{Margo Beasley}

The occupation of coal lumper receded from public view and from historical awareness as the use of coal for steam power declined through the last century. But in the early twentieth century coal lumpers were a substantial presence on the Sydney waterfront, because coal was essential for a steam-driven international economy. In Australia coal lumpers are often subsumed within the historically dominant wharf labourers' story because, like wharf labourers, they also loaded and unloaded ships, and in many ports unions representing the two occupations often amalgamated.

This was never the case in Sydney and the Sydney Coal Lumpers' Union and its members were always industrially and occupationally distinct from Sydney wharf labourers and their union. Unlike wharf labourers, who shifted all manner of cargoes between ship and shore, coal lumpers worked exclusively on coal and most, but not all, of that work took place out 'in the stream' as they put it, in Sydney Harbour, some distance from the wharves. Sydney coal lumpers saw themselves as akin to miners rather than wharf labourers and their main task was to move the coal from colliers or hulks that brought it to Sydney into other vessels.

Transcripts from two New South Wales Court of Arbitration cases in 1905, and oral histories, provide extensive evidence about the working conditions of unionised coal lumpers in Sydney, along with other aspects of their lives. Men from other places, such as Scandinavian sailors who jumped ship for instance, often married into the Sydney coal lumping community. In the New South Wales Royal Commission on Strikes of 1890-91, George Herbert, then secretary of the Sydney Coal Lumpers' Union, said it was 'generally the way that a young fellow coming from sea falls in love with a coal lumper's daughter. That's where we get our union from'.

Coal lumpers constituted a significant proportion of the population living around the early twentieth century Sydney industrial waterfront, particularly in Millers Point and The Rocks. But although they appear in high numbers on the electoral rolls, many coal lumpers were in fact only boarding on the waterfront for a few days each week while they worked, and their families, to whom they returned regularly, lived elsewhere in Sydney. Coal lumper Herman Nielsen, for instance, lived with his family at Willoughby on the northern side of Sydney Harbour, but rented a room at Millers Point for several days of each week. Nielsen said that most coal lumpers 'lived' at Millers Point under this kind of arrangement. Even those men who lived in nearby Pyrmont and Woolloomooloo had to rent a room for this purpose because they needed accommodation close to the work and somewhere to keep their filthy work clothes, and to wash and change, because they were too dirty to travel on public transport. 


\section{Working conditions}

Transcripts from two New South Wales Court of Arbitration cases in 1905 provide extensive detail on the Sydney coal lumpers' Dantesque working conditions. There were five categories of coal lumping work. The shovellers, winchdrivers and planksmen worked on the collier or hulk that was carrying and discharging the coal, and carriers and trimmers worked on the ship that was receiving the coal or being 'coaled'.

Coal lumpers' tools were basic: shovels, baskets, boots, ropes and their own brute strength. The 'gear' on the collier, which included winch, rope (called the 'fall') and baskets, had to be rigged so that the coal could be shifted from down below up to a suitable level on the deck for moving it into the ship that was to be coaled. The baskets were attached to a hook, which was fastened to the fall, which was run through a pulley and a winch on the deck above the hold.

In the hold of the collier the shovellers shovelled the loose coal into the lowered basket. The winchdriver winched the basket up to the deck, the planksman then carried the basket between the first ship and the second where the carriers took up the baskets and then emptied them into the hold or bunker of the second ship. Down there the trimmers redistributed the coal after it had been dropped in.

Shovellers' work was extraordinarily arduous. They used two kinds of shovels, a round-nosed shovel and a scoop. They each had to be fitted with special handles because they weren't strong enough for the load they had to carry and the new handle was also strengthened additionally with an iron ring. The height of the baskets was fixed by law at two feet and five inches (67 centimetres), which meant that the height of each lift was about two feet and six inches (69 centimetres) and the shoveller took about 16 pounds (7.2 kilograms) of coal in his shovel for each lift.

The extreme nature of shovelling was intensified by the men having to work on the uneven surface of loose coal and additionally, since there was no cessation once the movement of coal began, they were unable to straighten their backs. After two hours they couldn't stand any more, at which time they had a break. The men were also able to stop when the gear broke down, but mechanical improvements in the early twentieth century led to fewer breakdowns, thus fewer stops, and the work became more continuous and more exhausting as a result.

The safety of the shovellers depended more or less entirely on the skill and accuracy of the winchdriver. If a basket was brought up too quickly the heavy load of coal fell out onto the men below and could maim and/or kill them. The winchdriver's job was less physically laborious than that of many other coal lumpers, but it was enormously psychologically stressful and winchdrivers reputedly sometimes went mad. They had to stand at the winch for 14, 20, 30 or even 40 hours and had to avoid making a single slip. They spent very long hours on their feet, 
sometimes with hot steam pipes under them, and there was enormous strain on their eyes because they worked a great deal at night, or in poor light. Ultimately their eyes, feet or both would give way and they were no longer fit for the work.

Planksmen, like the shovellers, also depended on the winchdrivers for their lives. The planksman supervised the coal lumping work on the collier as he 'walked the plank' above the open hold. He instructed the winchdriver to bring the basket up when it was filled and once up, the baskets, which weighed up to 250 pounds (113.5 kilograms) when full, were mostly carried to the second vessel on the planksman's shoulders. As the basket rose he took hold of the fall, and when the basket reached the right height, he took it on his shoulder and ran with it to the end of the plank that reached over to the second vessel. Planksmen were at extreme physical risk for many reasons. They were on their feet continually, on a plank that was 16 inches (37 centimetres) wide and from which they could not get away. One coal lumper described planksmen's work thus:

At the risk of his life he travels the plank; suspended by a spar sometimes 30 feet [9 metres] from the deck. The planksman in one hour with 180 baskets has to travel 2,520 yards [2,304 metres], and handle a basket 360 times; he has to handle the basket twice each time - one to land it, one to take it again; you have to land one and put on another.

To maintain his balance the planksman had only himself and the fall. The fall was about one inch ( 2.3 centimetres) in diameter, thicker when wet, and men often wore gloves because it burned their hands. The smallest thing could throw the planksman off the plank. He could lose balance if the fall was run too quickly, or not at the correct height. The basket had to be lifted to the planksman's breast height but if the winchman couldn't see clearly or was insufficiently skilled he might heave it too high and topple the planksman who could tumble anywhere between 20 feet (6.1 metres) and 45 feet (13.7 metres) to the bottom of the hold.

A basket that was too low had a similar effect. Planksmen were also directly affected by weather conditions, especially high winds. They had very many industrial accidents and were apparently no good on the plank after years on the job because, as one witness to the Court of Arbitration put it, they 'lose their nerve'.

\section{Working on the coaled ship - carriers and trimmers}

When the planksman successfully delivered the basket across the plank to the second vessel the carrier took the basket on his shoulder from the planksman, carried it and dumped its contents down the chute to the hold or bunker, to the trimmers. A uniform pace was set for the carriers and they had to carry the baskets on their shoulders between 18 and 36 feet (5.4 to 10.9 metres), and sometimes up to 54 feet (16.4 metres), while keeping their place in the procession.

The men insisted on having a 20 second spell between getting rid of one basket and taking a fresh one. As with planksmen, there was no protection from the weather and sun in the summer time, 
and only the narrow alleyways to protect them in the rain. They crawled into these at times for shelter, but they could become very hot.

The carriers dumped coal into the bunker for three hours before the trimmers arrived. The trimmers' job was to 'trim' the received coal into the bunkers, spreading it to ensure even distribution of its weight and make it available for the use of the steamer. Bunkers were very dark and uninviting places that the trimmers entered by climbing down a chute. It took five or six minutes (of their own time) to 'get their eyes' when they got down into the hold and then the coal was sent down. Light in bunkers was always feeble and trimmers often worked by candlelight. To have their breaks they had to climb out via a rope in the chute (also in their own time), which caused additional strain on the knees. In some bunkers it wasn't possible to climb out unaided, so in an emergency they were dependent on the awareness and availability of others to haul them out.

Trimmers were exposed to specific occupational dangers. They took the coal in their shovels as it fell and threw it 12, 14 and even 20 feet (3.6 to 6 metres) and they had to build it up so that it lay level. Sometimes that meant they had to trim uphill, and the coal could suddenly shift or slide back down. The trimmer could be buried, and hurt or killed.

When the coal built up unevenly operations had to be suspended until the trimmers could move more coal to remedy the list. If the fireman of the ship opened the trap and the coal on which the trimmers were standing started to sink they could be 'drawn down' and suffocated. The air in the bunker was full of coal dust, which the men would spit for 20 hours after they had finished work. Work was sometimes suspended while the coal was watered to keep the dust down.

Some ships had 'pocket' bunkers constructed on top of boilers that held 60-70 tons of coal. When such a vessel went down there was no hope of the trimmers getting out. There could also be collisions between the collier and the vessel being loaded, and trimmers reportedly ran a higher risk of accident than coal miners. Trimmers often worked naked except for a loincloth and boots, because of the heat in the bunkers. When it was $66^{\circ} \mathrm{F}\left(19^{\circ} \mathrm{C}\right)$ on deck it might be $85^{\circ} \mathrm{F}\left(29^{\circ} \mathrm{C}\right)$ down below, but when they emerged to take a break they often sat on a wintry deck to eat their meals. The change of temperature was potentially deadly.

The effects of the heat and swallowed coal made the trimmers 'terribly sick at times' one coal lumper said, and they could be seen lying on the deck, 'gasping for breath'. One man reported that he had been dragged down in the bunkers and had nearly passed out. Another who survived being drawn down was nevertheless unable to work for some period subsequently because he had been spitting blood since. Men fainted and were sometimes almost delirious, because they had nearly suffocated. These conditions could cause men to be laid up for weeks because they were damaged internally by gas and foul air. 
Trimming was the least popular form of coal lumping work because trimmers were 'out of sight of daylight too long, they [were] underground too long' one man said. Men often started on the trimming when they commenced coal lumping but once they were 'broken in' they preferred to do the carrying or shovelling, or go on the plank or drive the winch.

\section{Night work and long hours}

At least half of coal lumping work was done at night and one coal lumper said he found that night work was 'very oppressive, and makes a person feel very miserable to work in those hours'. Although some vessels had rudimentary electric light and others had flare lamps, poor visibility at night increased occupational hazards. Smoke and haze from the lamps affected the carriers' sight, planksman couldn't see down the hatch and might drop an empty basket on a man below, and the winchman had difficulty judging exactly how high to heave the basket. Accidents were much more frequent at night than in the daytime. Another witness said of the night work:

At night time when you go aboard the collier you only have the deck to sit down on, and the dust, wind and rain all affect you, you have nowhere to go; in the alleyways the heat is so great in the colliers that you cannot stop 5 or 10 minutes before you get out.

He hated working at night and said he would 'feel all right up to 12 o'clock, and from 12 to 5 you feel half dead and if you were getting 5/- an hour [about three times the going rate] you would sooner go home and have a sleep'.

Poor working conditions were exacerbated by extraordinarily long hours. Fourteen hours was the average length of a job in the few years before 1905, but 20 was also common and shifts of 40 hours also occurred. Foremen, who were often non-union men, were sweated and sometimes worked 110 hours in a week. One foreman described working extraordinarily long hours, coaling the troop ships during the Boer War. He said 'I worked 111 constant. I never knocked off ... I had a bit of a sleep now and again. I had my clothes on and never had my boots unlaced for a week'. Another witness to the Court of Arbitration said

I think a man who works long hours gets a bit daft. Several of our men have died in the asylum. I think it is nothing but working long hours, and getting hit on the head with bits of coal.

Coal lumpers were employed casually and theoretically able to decline jobs that entailed extraordinarily long hours. But one witness said he did the very long shifts because it curried favour with the stevedore who allocated the work, and thus helped to retain access to the work in a highly competitive labour market. Although some jobs finished after a 14-hour stretch, the men might then take on another job, if they could get it, because they might not get any more work for a fortnight. 
Men were very compliant when they didn’t have much work, and were also prepared to put up with bad conditions for fear that they would lose access to it. Those in least favour usually got the worst and hardest work, but to be able to do coal lumping with any competence a man had to be used to it. Men who worked at coal lumping only one day a fortnight found the work much harder than those who did it more often. So the least able got the worst jobs, and suffered accordingly.

\section{Danger and disease}

Coal lumpers suffered many generalised health problems: bad backs, rheumatics, bad knees, varicose veins, rupture, broken ribs and conditions related to working in the wet. One man said he often worked in his singlet 'and the wet gets on your back and settles in the kidneys'. He had formerly been a carrier but had stopped doing that kind of work because it caused 'pressure on the heart'. One witness observed that men who had been carrying coal for a number of years were visibly two inches (4.6 centimetres) higher on one shoulder than the other. Another regarded coal lumping as 'the most detrimental of all kinds of work to a man.' He said that if he had any alternative work of any kind, 'I would take anything I could make a living at.'

It is likely that coal lumpers suffered high levels of silicosis, like miners, but the records of the Sydney Coal Lumpers' Union have long been lost and in the general statistics there is no breakdown for silicosis and the occupational category of coal lumper. But lung disease in general was mentioned in association with coal lumpers in newspaper reports of the period and there is other evidence to the effect that coal lumpers often died early from pneumonia or pleurisy. Industrial accidents were also rife, and were associated with falling great heights, and sharp, heavy lumps of coal falling on the men's heads, both causing deep wounds, broken and splintered bones, and, of course, death.

Billy Hughes, who later became Prime Minister of Australia, was president of the Sydney Coal Lumpers' Union in 1905, and also its advocate. He said coal lumping work 'finds out the weak places in a man. If a man has a weak spot in his heart, lungs or back, or ... say his nervous system is not all that it should be, he falls out.' Hughes argued that only the very strong remained in the work and coal lumpers aged 45 or 50 were simply 'the strongest who have survived', by natural selection.

Indeed, many men tried the work for a week or two, and even an hour or two, but they couldn't last. One coal lumper said that some men were forced to leave the work because they because they had started at too hard a pace and they were unable to keep going. Hughes judged that no other occupation called for the exercise of greater physical strength and endurance, supporting his assertion with two illustrations. Employers were unable to get sufficient men who could do coal lumping satisfactorily, or even unsatisfactorily, during strikes and lockouts; and the work 
necessitated certain conditions that didn't occur in any other trade: paid two hourly breaks, because a spell was 'absolutely essential for recuperation and food and rest'.

Union secretary George Herbert complained in a letter to the Sydney Collier Owners’ Association that it required 'physical giants' for the kind of work it wanted done and that 'there are not ten men out of every hundred in the State that could do sufficient work to satisfy you'. One union member complained that coal lumping conditions on land, at the Mortlake gas works, were the most extreme of all. According to Alfred Hutchinson fewer than 50 men in the Sydney Coal Lumpers' Union could tolerate the work there. They handled huge tubs holding 2-3 tons of coal. Each tub was swung on a crane and grabbed by the men as it came down and then the men had 'to run the tub right into the coal' Hutchinson said. Coal lumping there was 'not work but slaughter,' and 'If you don't look out you get an arm or a leg broken. You are liable to get smashed up any minute'.

It is not possible to get any specific statistics on coal lumpers and morbidity. It is likely, for instance, that they suffered high levels of silicosis, as coal miners did, but there is little available evidence to that effect. However, lung disease in general was mentioned in association with coal lumpers in some newspaper reports of the period and one of the oral history interviewees recalled that coal lumpers often died early from pneumonia or pleurisy. The records of the Sydney Coal Lumpers' Union no longer exist and there is no breakdown in any general statistics on accidents into the category of coal lumper. However, in the Court of Arbitration in 1905, union representatives referred to members who had died or suffered serious injury in preceding years.

Winchman John Pearson had had the muscle of his left arm torn out when it got jammed in the winch on the Dangerfield. It took about one and a half hours to release his arm and the accident 'took the muscles clean off'. Sam Taylor fell off the plank on the Kurrajong, lived a few days and then died. It was thought he may have missed his step or become dizzy, but in any event when an empty basket fell down into the hold, Taylor went with it. A planksman called Kelly fell on the Illaroo because the winchdriver was inexperienced and lifted the basket too high. Kelly overbalanced and fell.

Archibald Henderson was killed on the Wallsend. He fell face down and sustained a wound so severe that 'you could shove your hand inside him'. Henderson also cut his face, broke his thigh and the bone in his arm splintered. 'I had him on my lap for about an hour and a half before they took him to shore,' his mate remembered, saying the accident wouldn't have happened if there had been proper gear for receiving coal. Mick Duggan was killed on the Australian Steam Navigation Company's Phoebe when he was struck in the head. Another coal lumper, called McLeod, was killed on the Tonkin, as was a man named Perkinfeldt on the Tasmania. John Gilmore was killed on the Aldinga at Smiths Wharf, Charles Thompson on the Governor Blackall, and George Clarke on the Herga. When this evidence was being given in 1905 James 
Sealy was the most recent accident victim. He fell 35 feet (10.6 metres) into the collier Mount Kembla when a full basket struck him in its journey. At that stage he was believed to be at the point of death.

Because of their physical strength and arduous working conditions in the early twentieth century, Sydney coal lumpers earned a higher hourly rate than even wharf labourers, and thus may have been the most highly paid casual labour in Australia at that time.

Dr Margo Beasley is a Sydney-based consultant historian and author.

\section{References}

Margo Beasley, 'Sarah Dawes and the Coal Lumpers: Absence and Presence on the Sydney Waterfront 1900-1917', PhD thesis, University of Wollongong, 2004, http://www.library.uow.edu.au/adt-NWU/uploads/approved/adt-

NWU20050720.135615/public/01Front.pdf 